\title{
Characterizing Uranium Solubilization Under Natural Near Oxic Conditions
}

\author{
Chicgoua Noubactep ${ }^{1}$, Dirk Merten ${ }^{2}$, Till Heinrichs ${ }^{1}$, Jürgen Sonnefeld ${ }^{3}$, Martin \\ Sauter ${ }^{1}$ \\ ${ }^{1}$ Geowissenschaftliches Zentrum der Universität Göttingen; Goldschmidtstr. 3, D \\ - 37077 Göttingen \\ ${ }^{2}$ Institut für Geowissenschaften der Friedrich-Schiller-Universität Jena; Burgweg \\ 11, D - 07749 Jena; \\ ${ }^{3}$ Institut für Physikalische Chemie der Friedrich-Schiller-Universität Jena; Les- \\ singstrasse 10; D - 07743 Jena
}

\begin{abstract}
A 782 d solubilization study using not shaken batch experiments and involving one uranium-bearing rock and three natural carbonate minerals was conducted to characterize uranium $(\mathrm{U})$ leaching under oxic conditions. Results showed that aqueous $U$ concentration increased continuously with a solubilization rate of $0.16 \mu \mathrm{gm}^{-2} \mathrm{~h}^{-1}$ for the first $564 \mathrm{~d}(1.5 \mathrm{y})$. After $1.5 \mathrm{y}$, U concentration reached a maximum value (saturation) and decreased afterwards. The saturation concentration of $54 \mathrm{mgL}^{-1}$ (mean value) was influenced to various extent by the presence of carbonate minerals. Dissolution/precipitation, adsorption or ion exchange processes appear to control U solubilization.
\end{abstract}

\section{Introduction}

Contamination of soils and groundwater with uranium (U) has been observed at several former mining sites worldwide, posing hazards to human health (e.g. Jerden and Singa 2003, Junghans and Helling 1998). U has a very long half-live (4.5 $10^{9}$ years) and can circulate in the environment for millions of years. Therefore, a thorough clean-up of contaminated sites should be performed immediately once pollution occurs. $U$ retention in the soil matrix through processes such as sorption or ion exchange cannot reduce the potential adverse effects of this long-lived radionuclide (e.g. Langmuir 1997, Lee et al. 2005; Naftz et al. 2002). Therefore, methods have been developed which could enable complete U extraction from soil 
and groundwater and its eventual subsequent appropriate treatment (e.g. Lee et al. 2005). One of the most favourite methods consists in immobilizing $U$ in permeable reactive barriers (PRB). $\mathrm{U}$ immobilization in $\mathrm{PRB}$ can be biotic and/or abiotic (Naftz et al. 2002).

Regardless from the nature of $U$ immobilizing processes in a PRB, the pollutant has to be solubilized (e.g. from tailing materials) and transported to the barrier. U solubilization from soils and mine tailings and its subsequent transport to the PRB is the result of interactions in the local system "natural water-geomaterials" (Felmy et al. 2002, Froment et al. 2002). The kinetics of U solubilization at each site will depend on the interactions between local geochemistry and infiltrating natural water. However, available data on $U$ solubilization are mostly gained from leaching experiments performed on synthetic samples with technical solutions; so called lixiviants: $\left(\mathrm{NH}_{4}\right)_{2} \mathrm{CO}_{3}, \mathrm{Na}_{2} \mathrm{CO}_{3}, \mathrm{NaHCO}_{3}, \mathrm{H}_{2} \mathrm{SO}_{4} \ldots$ (Elles and Lee 1998, Kaplan and Serkiz 2001, Noubactep et al. 2005).

The main reactions taking place between water and mineral phases in the subsurface fall into four main categories: dissolution/precipitation reactions, exchange reactions, acid-base reactions, and redox reactions (Elles and Lee 1998, Wilson 2004). Together with sorption/desorption processes, these interactions control contaminant mobilization/retardation in the environment. Discussing whether sorption/desorption processes or mineral dissolution/precipitation controls the levels of soluble $U$ in nature has been an interesting research area (e.g. Elles and Lee 1998). Highly natural sorptive materials of concern include organic matter and $\mathrm{Al} / \mathrm{Fe} / \mathrm{Mn} / \mathrm{Ti}$ oxyhydroxides. In the absence of sorptive materials, dissolution/precipitation reactions, exchange reactions, acid-base reactions, and redox reactions are expected to control U solubilization. The overall kinetics of U(VI) dissolution is relative rapid compared that of U(IV) oxidation. Therefore, it is expected that acid-base and dissolution/precipitation reactions will dominate interactions between water and minerals under oxic conditions.

Short term shaken laboratory batch experiments are commonly performed when investigating U solubilization from environmental samples (Carroll et al. 1998, Eless and Lee 1998, Felmy et al. 2002, Kaplan and Serkiz 2001). Alternatively, long term non stirred batch experiments involving solution replacement are conducted (e.g. Froment et al. 2002). Such experimental conditions are not appropriate for all environmental scenarios. For instance, if groundwater inflow in a subsurface area is faster than the outflow, a quasi-stagnation will be observed. In such regions, groundwater residence time can be long enough to be simulated by not shaken batch experiments.

The widespread approach to characterize the environmental behavior of trace metals and radionuclides consists in performing well-controlled laboratory experiments with synthetic model substances and then use the results to better understand more complex natural systems (Carroll et al. 1998, Malmström et al. 2000). Therefore, an important gap exists between laboratory experiments and field observations (Malmström et al. 2000). It can be expected that performing laboratory experiments with natural samples could help to bridge this gap (Noubactep 2003). 
The objective of this study was to characterize $U$ solubilization from a multimineralic rock under quasi-stagnating oxic conditions. For this purpose not shaken batch experiments were conducted with tap water and a fixed amount of an U-bearing rock $\left(8 \mathrm{gL}^{-1}\right)$ and three carbonate bearing additives (calcite, dolomite and vaterite -8 to $48 \mathrm{gL}^{-1}$ ) for experimental duration of up to two years (782 days). While U-bearing rock was used to mimic tailing materials, the three natural additives of different solubility have been added in order to characterize the effect of $\mathrm{CO}_{3}{ }^{2-}$-bearing minerals on $\mathrm{U}$ solubilization. Carbonate mineral weathering by tap water could provide elevated $\mathrm{CO}_{3}{ }^{2-}$ concentrations as encounter in nature as result of microbial activity. It is expected that association of aqueous $\mathrm{U}$ with $\mathrm{CO}_{3}{ }^{2-}$ to form soluble aquo-complexes such as $\mathrm{Ca}_{2}\left[\mathrm{UO}_{2}\left(\mathrm{CO}_{3}\right)_{3}\right] 10 \mathrm{H}_{2} \mathrm{O}$ (Bernhard et al. 2001) will enhance aqueous $U$ solubility and promote rock dissolution.

\section{Experimental Section}

Batch experiments without shaking were conducted. The batches consisted in mixtures of constant amounts of an U-bearing rock $\left(8 \mathrm{gL}^{-1}\right)$ and a carbonate mineral (calcite, dolomite, vaterite), respectively. Equilibration times varied from 14 to 782 days. A further experiment without carbonate mineral (rock alone) was conducted. Thus, the extent of $U$ solubilization by tap water (simulant for seepage water - Noubactep 2003) as influenced by carbonate minerals was characterized.

Uranium solubilization was initiated by adding $13.0 \mathrm{~mL}$ of a tap water to $0.1 \mathrm{~g}$ of the U-bearing rock and $0.1 \mathrm{~g}$ of each additive in glass essay tubes at laboratory temperature (about $21^{\circ} \mathrm{C}$ ). The used tap water of the city of Jena (Thuringia, Germany) has a composition (in $\mathrm{mgL}^{-1}$ ) of $\mathrm{Cl}^{-}: 15.72 ; \mathrm{NO}_{3}^{-}: 10.0 ; \mathrm{SO}_{4}^{2-}: 72.1$; $\mathrm{HCO}_{3}{ }^{-}: 270 ; \mathrm{Na}^{+}: 8.72 ; \mathrm{K}^{+}: 5.28 ; \mathrm{Mg}^{2+}: 29.3$ and $\mathrm{Ca}^{2+}: 80.9$. Initial $\mathrm{pH}$ was 7.4. At selected dates, 0.05 to $0.25 \mathrm{~mL}$ of the supernatant solution was retrieved at the top of each tube for $U$ analysis. The aqueous $U$ concentration was recorded as a function of time.

The used U-bearing rock was crushed and sieved. The fraction 0.250 to 0.315 $\mathrm{mm}$ was used without any further pre-treatment. The rock contains around $2.3 \%$ $\mathrm{U}$ and is further composed of: $81.25 \% \mathrm{SiO}_{2}, 0.14 \% \mathrm{TiO}_{2} ; 7.36 \% \mathrm{Al}_{2} \mathrm{O}_{3}, 1 \%$ $\mathrm{Fe}_{2} \mathrm{O}_{3}, 0.01 \% \mathrm{MnO} ; 0.48 \% \mathrm{MgO}, 0.67 \% \mathrm{CaO}, 1.19 \% \mathrm{Na}_{2} \mathrm{O}, 1.48 \% \mathrm{~K}_{2} \mathrm{O}, 0.36$ $\% \mathrm{P}_{2} \mathrm{O}_{5}$ and $0.01 \% \mathrm{SO}_{3}$.

Calcite $\left(\mathrm{pK}_{\mathrm{sp}}=8.48 ; \mathrm{SiO}_{2}: 0.3 \%, \mathrm{MgO}: 1.02 \%, \mathrm{CaO}: 55.1 \%\right)$, dolomite $\left(\mathrm{pK}_{\mathrm{sp}}\right.$ $\left.=17.09 ; \mathrm{SiO}_{2}: 1.2 \%, \mathrm{MgO}: 20.3 \%, \mathrm{CaO}: 31.0 \%\right)$ and vaterite $\left(\mathrm{pK}_{\mathrm{sp}}=8.34 ; \mathrm{SiO}_{2}\right.$ : $0.5 \%, \mathrm{MgO}: 1.12 \%, \mathrm{CaO}: 55.0 \%$ ) minerals were crushed, sieved and the fraction 0.63 to $1.0 \mathrm{~mm}$ was used. It is expected that their dissolution will increase the kinetic and the extent of $U$ solubilization. Calcite and dolomite were selected because of their natural abundance (Elfil and Roques 2004, Sherman and Barak 2000). Although vaterite is almost rare in the nature, it was used in this study because it has some features such as high specific surface area and high solubility compared with calcite (Su and Wu 2004). 
Dissolved U concentrations were measured with inductively coupled plasma mass spectrometry (ICP-MS, PQ3-S, ThermoElemental) because of its higher sensitivity and fast analysis speed. The quality of the analyses was checked using synthetic standards. The instrumental precision, determined as \pm 1 standard deviation for three runs on the same sample and was better than $5 \%$.

The $\mathrm{pH}$ value was measured by combination glass electrodes (WTW Co., Germany). All experiments were performed in triplicate. Error bars given in figures represent the standard deviation from the triplicate runs.

In all experiments, dissolved $U$ was normalized to rock surface area $\left(3.53 \mathrm{~m}^{2} \mathrm{~g}\right.$ ${ }^{1}$ ), solution volume (using $0.013 \mathrm{~L}$ for all runs) and rock concentration $\left(7.69 \mathrm{gL}^{-1}\right)$. Rock dissolution rates $\left(\mu \mathrm{g} \mathrm{Um}^{-2} \mathrm{~h}^{-1}\right)$ were determined from the slopes of linear regressions of normalized $U$ concentration released versus time including the point $(0,0)$. The calculated uncertainty of the slopes ranged from 2.1 to $14.2 \%$.

SEM analyses: Crushed grains of the rock sample were C-coated and examined by scanning electron microscopy (SEM) and mineral phases were identified by semi-quantitative energy dispersive X-ray analysis (EDX) using a LEO1530 Gemini microscope equipped with an OXFORD Inca analytical system. The accelerating voltage was $25 \mathrm{kV}$, probe current ca $150 \mathrm{nA}$, counting time $60 \mathrm{sec}$.

\section{Results and Discussion}

\section{SEM Observations}

Qualitative SEM-EDX examinations of a rock sample provided direct information on rock composition that complemented information obtained from X-ray fluorescence analyses (experimental section). The EDX analysis revealed that the used $\mathrm{U}$-bearing rock is a multimineralic rock containing among others uraninite $\left(\mathrm{UO}_{2}\right)$, arsenopyrite ( $\mathrm{FeAsS}$, ), and galena $(\mathrm{PbS})$. Associations of $\mathrm{U}$ with arsenopyrite was also encountered. The gangue mainly consists of alkali-feldspars and quartz.

\section{Uranium solubilization}

After the determination of the aqueous $\mathrm{U}$ concentration $(\mathrm{C}=$ mean value of a triplicate) at any time, the corresponding standard deviation $(\sigma)$ was calculated and the relative error $\left(\mathrm{P}_{\mathrm{r}}=100 * \sigma / \mathrm{C}\right.$; in $\left.\%\right)$ was deduced. At the end of the experiment $\mathrm{pH}$ values ( 7.8 to 8.4 for the eight systems) and aqueous concentrations of selected elements were determined. To characterize U solubilization from the multimineralic rock while taking individual properties of $\mathrm{CO}_{3}$-bearing rocks into account, four different experiments have been performed over a duration up to $782 \mathrm{~d}$ $(2.14 \mathrm{y})$ with $8 \mathrm{gL}^{-1} \mathrm{U}$ rock and 0 or $8 \mathrm{gL}^{-1}$ additive: I) rock alone, II) rock + vaterite, III) rock + calcite, and IV) rock + dolomite (system I, II, III and IV). Additional experiments were conducted in system III with 16,32 and $48 \mathrm{gL}^{-1}$ calcite 
[systems IIIa, IIIb and IIIc] and in system IV with $48 \mathrm{gL}^{-1}$ dolomite [system IVc] to access the influence of $\mathrm{CO}_{3}{ }^{2-}$-mineral amount on $\mathrm{U}$ solubilization.

\section{Kinetics of $U$ solubilization}

Fig. 1 summarizes the variation of the $\mathrm{U}$ concentration $\left(\mathrm{C}\right.$ in $\left.\mu \mathrm{gL}^{-1}\right)$ and the relative error $\left(\mathrm{P}_{\mathrm{r}}\right.$ in \%) within the triplicates as a function of time for U-bearing rock in tap water (system I). It can be seen that $\mathrm{C}$ increases continually with the time from the start of the experiment $(\mathrm{t}=0)$ to a maximum at $\mathrm{t}=564 \mathrm{~d}$, afterwards $\mathrm{C}$ slowly decreases throughout the end of the experiment (day 782). For $t \leq 564 d$, the rate of $\mathrm{U}$ solubilization $\left(\mu \mathrm{gm}^{-2} \mathrm{~h}^{-1}\right)$ was defined as the slope of the straight line $\mathrm{C}=\mathrm{a} * \mathrm{t}$. The obtained rate of $\mathrm{U}$ solubilization $\left(\mathrm{a}=0.16 \mu \mathrm{gm}^{-2} \mathrm{~h}^{-1}\right)$ was very comparable to that of amorphous silica reported by $\mathrm{Xu}$ and Pruess (2000). This value is by far smaller than $0.78 \mu \mathrm{gm}^{-2} \mathrm{~h}^{-1}$ obtained under atmospheric conditions in air homogenized batch experiments (Noubactep et al. 2005). The difference is easily explained by the slowness of diffusive processes in the present work.

The plot of the variation of the relative error $\left(\mathrm{P}_{\mathrm{r}}\right)$ shows a maximum $(41 \%)$ at the beginning of the experiment $(t=14 \mathrm{~d})$. This value continuously decreases to a minimum of $4 \%$ at $t=564 \mathrm{~d}$, afterwards $\mathrm{P}_{\mathrm{r}}$ increases to $20 \%$ at the end of the experiment $(\mathrm{t}=782 \mathrm{~d})$. The maximum value of $\mathrm{C}\left(\mathrm{C}_{\max } ; \mathrm{U}\right.$ saturation $)$ coincides with the minimum value of $P_{r}$ suggesting that, around $t=564 d$, the system is closed to a steady state ("pseudo-equilibrium"). The measured $C_{\max }\left(54 \mathrm{mgL}^{-1}\right)$ is comparable to reported values at some contaminated sites (Jerden and Sinha 2003, Junghans and Helling 1998), validating the capacity of the experimental procedure (not shaken closed batch systems) to simulate certain field conditions. While performing similar experiments at atmospheric pressure $\left(\mathrm{P}_{\mathrm{CO} 2}=0.035 \%\right)$, Noubactep et al. (2005) reported an $\mathrm{U}$ concentration of $8.3 \mathrm{mgL}^{-1}$ at pseudo-equilibrium $(\mathrm{pH}$ 7.8). This value is obviously larger than that predicted by the solubility of schoepite $\left(10^{-5} \mathrm{M}\right.$ or $2.4 \mathrm{mgL}^{-1}$, Noubactep 2003), but thermodynamic equilibria are rare in nature (Meinrath and May 2002). Therefore the present experiments can be helpful to explain some observations in the real nature.

The evolution of $\mathrm{C}$ results from several complex processes: $\mathrm{U}$ leaching from rock, $\mathrm{U}$ sorption onto rock by-minerals (e.g. $\mathrm{Al}_{2} \mathrm{O}_{3}, \mathrm{SiO}_{2}$ ), $\mathrm{U}$ precipitation from the aqueous phase (e.g. $\mathrm{UO}_{3} \cdot 2 \mathrm{H}_{2} \mathrm{O}$ ). It can be emphasized that, during the first phase of the experiment $(0 \leq t(d) \leq 564) U$ releasing processes are dominating. At $t>$ $564 \mathrm{~d}$, U precipitation dominates since $\mathrm{U}$ concentration decreases. The characterization of individual processes (adsorption, complexation, precipitation...) responsible for the evolution of $\mathrm{C}$ under the experimental conditions of this work is not possible. However, the objective of this study is not to accurately define the systems in which the materials (U-bearing rock and $\mathrm{CO}_{3}$-minerals) are involved, but rather to characterize the effect of the minerals on $\mathrm{U}$ solubilization qualitatively. Therefore, the evolution of other systems (system II, III and IV) will be compared to that of the reference system (system I) while characterizing system evolution by the rate of $\mathrm{U}$ solubilization and the trend in the variation of both $\mathrm{C}$ and $\mathrm{P}_{\mathrm{r}}$. 


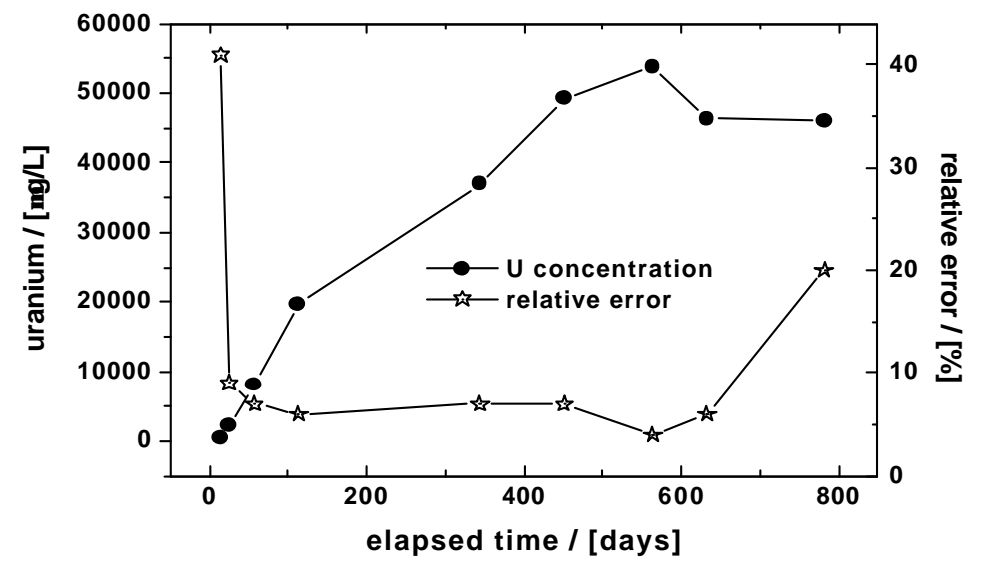

Fig.1: Variation of the uranium concentration $(\mu \mathrm{g} / \mathrm{L})$ and the relative error $(\%)$ within the triplicates as a function of time for the reference system (U-bearing rock in tap water).

Table 1. Variation of the relative error (\%) in the individual systems as function of the time.

\begin{tabular}{|c|c|c|c|c|c|c|c|c|}
\hline \multirow{2}{*}{$\begin{array}{c}\mathbf{t} \\
\text { (days) }\end{array}$} & \multicolumn{8}{|c|}{ system } \\
\hline & $T$ & $\pi$ & IIII & TV & IIIa & TाIb & IIIc & TVc \\
\hline 14 & 41 & 106 & 14 & 21 & 20 & 24 & 26 & 13 \\
\hline 25 & 9 & 71 & 9 & 43 & 30 & 11 & 45 & 43 \\
\hline 57 & 7 & 39 & 6 & 23 & 21 & 9 & 9 & 15 \\
\hline 113 & 6 & 3 & 5 & 8 & 8 & 11 & 5 & 6 \\
\hline 344 & 7 & 10 & 2 & 13 & 6 & 11 & 2 & 9 \\
\hline 451 & 7 & 14 & 2 & 12 & 5 & 13 & 2 & 8 \\
\hline 564 & 4 & 8 & 2 & 8 & 4 & 5 & 7 & 11 \\
\hline 633 & 6 & 12 & 3 & 11 & 5 & 11 & 3 & 9 \\
\hline 782 & 21 & 11 & 1 & 11 & 7 & 11 & 1 & 9 \\
\hline
\end{tabular}

\section{Effect of the nature of carbonate minerals}

Fig. 2 ( $a$ and b) summarizes the results of the U solubilization in systems I, II, III and IV and table 1 gives the variation of the relative error with the experimental duration in all the systems. From figure $2 \mathrm{a}$ it can be seen that the best $\mathrm{U}$ solubilization rate for the first 250 days is achieved when vaterite is present (system II), attesting that $\mathrm{U}$ solubilization is affected by the presence of $\mathrm{CO}_{3}{ }^{2-}$-minerals. Apart from vaterite, all other minerals reveal lower $\mathrm{U}$ solubilization during the first 100 days of the experiment (Fig 2a). This observation suggests either that: (1) U solu- 
bilization is inhibited by the presence of certain $\mathrm{CO}_{3}{ }^{2-}$-minerals, (2) solubilized $\mathrm{U}$ is adsorbed on rock materials until its sorption capacity is exhausted, or (3) the amount $\mathrm{CO}_{3}{ }^{2-}$-ions from mineral dissolution is insufficient to solubilize adsorbed $\mathrm{U}$ from rock materials.

The first hypothesis is an absurdity since vaterite and calcite are of almost of the same chemical composition. Therefore, it can be assumed that once $\mathrm{U}$ is leached from the rock, it is sorbed to rock by-materials until sufficient $\mathrm{CO}_{3}{ }^{2-}$-ions are generated to form soluble $\mathrm{U}$ complexes. Thus vaterite with the highest solubility could enhance $\mathrm{U}$ solubilization already in the early stage of the experiment. For other minerals this enhancing effect was delayed due to their lower solubility.

The solubilization efficiency is the lowest when calcite is present (system III); this observation is confirmed by the values of the rate of $U$ solubilzation (Tab. 2). For longer experimental durations (up to 564 days, figure 2b), system III still exhibits the smallest $\mathrm{U}$ solubilization rate whereas system II and IV (vaterite and dolomite) significantly increase U solubilization comparatively to the reference system. The solubilization enhancement was the highest in the presence of dolomite (system IV). These observations can not be explained by the relative solubility of the mineral, since dolomite is by far less soluble than calcite and vaterite. It should be kept in mind that solubility products are defined for pure phases. The evolution of the relative error $\left(\mathrm{P}_{\mathrm{r}}\right.$, table 1) shows that the mineral dissolution is a complex process. In fact, system II exhibits the largest variation of $\mathrm{P}_{\mathrm{r}}$-values in the initial phase (up to $105 \%$ ) which then rapidly decreases to $3 \%$ after 113 days. Apart from system IV (dolomite) for which the $\mathrm{P}_{\mathrm{r}}$-value was not maximal at the beginning of the experiment (14 days) all other additives presented the same evolution of $\mathrm{P}_{\mathrm{r}}$ as the reference system with the difference that no minimum was attained but rather a relative constant value at the end of the experiment $(t>300 \mathrm{~d})$. The fact that the curve of $\mathrm{P}_{\mathrm{r}}$-value did not reach a minimum as for system I illustrates the complexity of the processes determining $\mathrm{C}$ under experimental conditions. Since $\mathrm{CO}_{3}{ }^{2-}$-mineral dissolution was not at equilibrium it can be emphasized that $\mathrm{C}$ decrease results from precipitation (e.g. $\mathrm{UO}_{2} \cdot 2 \mathrm{H}_{2} \mathrm{O}, \mathrm{UO}_{2} \mathrm{CO}_{3}$ ), co-precipitation (e.g. $\left.\mathrm{CaUO}_{2}\left(\mathrm{CO}_{3}\right)_{2}\right)$ and $\mathrm{U}$ incorporation into the structure of $\mathrm{CO}_{3}^{2-}$-minerals.

\section{Effect of the amount of carbonate minerals}

To further investigate the impact of $\mathrm{CO}_{3}{ }^{2-}$-minerals on $\mathrm{U}$ solubilzation and particularly the possibility of $\mathrm{U}$ incorporation into the structure of $\mathrm{CO}_{3}{ }^{2-}$-minerals (e.g. Reeder et al. 2000) larger amount of calcite and dolomite were tested in systems III (IIIa, IIIb, IIIc) and IV (IVc). If the impact of U incorporation into the structure of calcite and dolomite is important, then U concentration in systems IIIc and IVc (48 g.L $\mathrm{L}^{-1}$ additive) will be significantly lower than in system III and IV (8 g.L $\mathrm{L}^{-1}$ additive) at any time. The results for system III showed that during the whole experiment, system III ( 8 g. $\mathrm{L}^{-1}$ calcite) exhibits the lowest U solubilization whereas the evolution of systems with other calcite amounts $\left(16,32\right.$ and 48 g. $\left.\mathrm{L}^{-1}\right)$ was very close to that of the reference system. Therefore, for calcite higher mineral amount enhances U solubilization. For dolomite (system IV), U solubilization was higher in system IV $\left(8 \mathrm{~g} . \mathrm{L}^{-1}\right)$ than system IVc $\left(48 \mathrm{~g} . \mathrm{L}^{-1}\right)$ from the start of the experiment 
to $\mathrm{t}=400 \mathrm{~d}$, afterwards the inverse occurs. These observations suggest that $\mathrm{U}$ incorporation into mineral structure is more likely to occur in dolomite that in calcite. In both cases, $\mathrm{P}_{\mathrm{r}}$-value variation was minimal in the system with the highest mineral amount (IIIc and IVc).
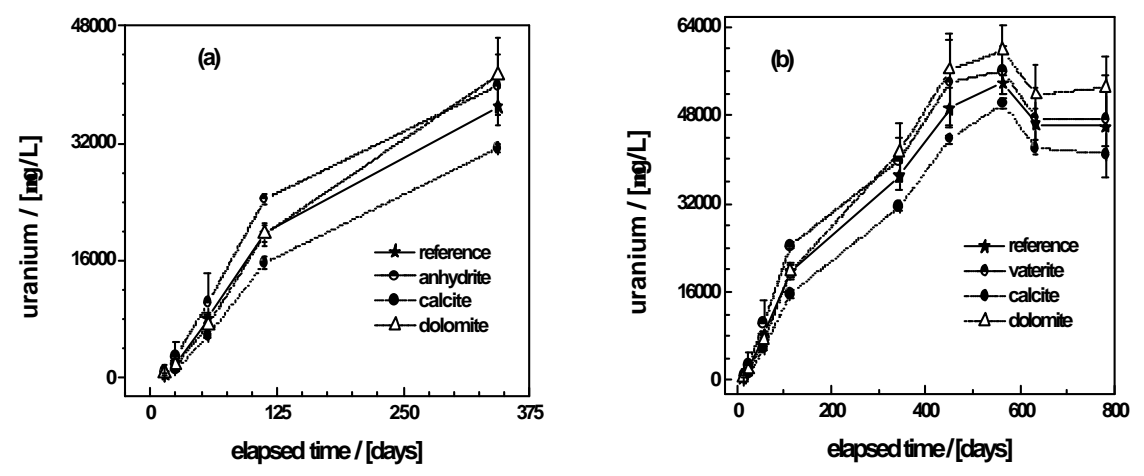

Fig.2: Comparison of U(VI) solubilization as influenced by used carbonate minerals for 344 days (a) and 782 days (b). For clarity, only the plots for the reference system (system I) and the systems with $8 \mathrm{~g} / \mathrm{L}$ additives (system II, III \& IV, see text) are presented. The experiments were conducted in triplicates. Error bars give standard deviations. The lines are represented to facilitate visualization.

Table 2: $\mathrm{Co}, \mathrm{Ni}, \mathrm{Pb}, \mathrm{Sb}, \mathrm{Sr}$ and $\mathrm{U}$ concentrations as measured in different systems at the end of the experiment (782 d). a $\left(\mu \mathrm{gm}^{-2} \mathrm{~h}^{-1}\right)$ is the rate of $U$ solubilization. The absolute element concentration $([\mathrm{X}]$ in $\mu \mathrm{g} / \mathrm{L})$ of system $\mathrm{I}$ is given in the first line and serves as reference for the definition of the relative concentration. The ebments are ranged in the order of increasing relative concentration for system II from the left to the right.

\begin{tabular}{cccccccc}
\hline System & $\begin{array}{c}\mathrm{a} \\
\mu \mathrm{gm}^{-2} \mathrm{~h}^{-1}\end{array}$ & ${ }^{121} \mathrm{Sb}$ & ${ }^{238} \mathrm{U}$ & ${ }^{208} \mathrm{~Pb}$ & ${ }^{88} \mathrm{Sr}$ & ${ }^{60} \mathrm{Ni}$ & ${ }^{60} \mathrm{Co}$ \\
\hline$[\mathrm{X}]\left(\mu \mathrm{gL}^{-1}\right)$ & & 28 & 55.000 & 116 & 360 & 0.55 & 0.09 \\
I & 0.16 & 100 & 100 & 100 & 100 & 100 & 100 \\
II & 0.17 & 52 & 105 & 172 & 215 & 565 & 980 \\
III & 0.14 & 59 & 92 & 128 & 99 & 105 & 138 \\
IV & 0.18 & 69 & 114 & 131 & 107 & 108 & 77 \\
IIIa & 0.16 & 57 & 103 & 129 & 101 & 161 & 187 \\
IIIb & 0.17 & 61 & 105 & 183 & 108 & 186 & 552 \\
IIIc & 0.17 & 59 & 106 & 114 & 103 & 111 & 192 \\
IVc & 0.17 & 46 & 110 & 132 & 107 & 187 & 220 \\
\hline
\end{tabular}


433 Characterizing Uranium Solubilization Under Natural Near Oxic Conditions

\section{Solubilization of other elements}

In order to gain an insight on the solubilization behaviour of other components of the multimineralic rock, the concentration of nine (9) elements was determined at the end of the experiment $(\mathrm{t}=782 \mathrm{~d})$ : $\mathrm{Co}, \mathrm{Ni}, \mathrm{Cu}, \mathrm{Zn}, \mathrm{Rb}, \mathrm{Sr}, \mathrm{Sb}, \mathrm{Ba}$ and $\mathrm{Pb}$. Table 5 presents the results for five selected elements together with that of U. The absolute concentration ( $\mathrm{C}$ - mean value of triplicates) of each element in the reference system is given. For other systems the relative concentrations are given. The relative concentration $\left(\mathrm{P}_{\mathrm{r}}{ }^{\prime}\right.$ in $\left.\%\right)$ is defined as $100 * \mathrm{C} / \mathrm{C}_{\mathrm{ref}}$. Such that for system $\mathrm{I}$ (reference) $\mathrm{P}_{\mathrm{r}}{ }^{\prime}=100 \% ; \mathrm{P}_{\mathrm{r}}{ }^{\prime}>100 \%$ when a $\mathrm{CO}_{3}{ }^{2-}$-mineral enhances element solubilization and $\mathrm{P}_{\mathrm{r}}{ }^{\prime}<100 \%$ when a mineral inhibits element solubilization.

From table 5 it can be seen that, apart from $\mathrm{Sb}, \mathrm{CO}_{3}{ }^{2-}$-minerals enhance solubilization of all other elements. The extent of the solubilization modification varies from $46 \%$ for $\mathrm{Sb}$ in system IVc to $980 \%$ for Co in system II (calcite). It would have been interesting to follow the evolution of several of these elements with time. To characterize target mixed contamination scenarios, one or more metalbearing rocks can be mixed similar as in this study for solubilization studies.

\section{Conclusions}

The mixture of $\mathrm{U}$ - and $\mathrm{CO}_{3}{ }^{2-}$-bearing minerals has revealed that adsorption, solution/precipitation and $U$ incorporation in mineral structures are determinant in discussing $U$ solubilization. In nature, the situation will be complicated by organic ligands derived from decomposing organic matter or from the direct activities of soil microbes or plant roots (e.g. Wilson 2004). In closed areas in the environment $U$ concentration can reach very high values. The extent of $U$ transport from such areas into the environment for instance after a rainfall or any other water supplying event depends on site specific geochemical conditions. When sufficient amount of organic matter and/or $\mathrm{Al} / \mathrm{Fe} / \mathrm{Mn} / \mathrm{Ti}$ oxyhydroxides is present, $\mathrm{U}$ transport can be significantly retarded, if groundwater flow is slow enough to allow adsorption equilibrium. Otherwise $\mathrm{U}$ can be transported to distances up to hundreds of kilometers in relatively short times (Lee et al. 2005). Field and laboratory studies suggest that both dissolution/precipitation of U-bearing minerals and adsorption/desorption reactions are the most important processes in the attenuation or release of U (e.g. Elless and Lee 1998). However, attempts have been made to deduce the nature of mineral phases from $U$ concentrations via thermodynamic arguments. This work has shown that under stagnant conditions metastable states can persist over months. Therefore any attempt to determine solubility limiting phases from field U concentration is uncertain (Fanghänel \& Neck 2002).

The results of the present study indicate that investigating the dissolution from multimineralic rocks can be a powerful tool to characterize multi-contaminant systems. Further testing of mineral-water systems under various experimental conditions is asked for, to verify capacity of such systems to describe natural processes. 


\section{Acknowledgments}

This work was supported by the German science foundation (Deutsche Forschungsgemeinschaft; DFG-Sa 501/15-1).

\section{References}

Bernhard G, Geipel G, Reich T, Brendler V, Amayri S, Nitsche H (2001) Uranyl(VI) carbonate complex formation. Radiochim Acta 89: 511-518.

Carroll SA, O'Day PA, Piechowski M (1998) Rock-Water Interactions Controlling Zinc, Cadmium, and Lead Concentrations in Surface Waters and Sediments, U.S. Tri-State Mining District. Environ Sci Technol 32: 956-965.

Elfil $\mathrm{H}$, Roques $\mathrm{H}$ (2004) Prediction of the limit of the metastable zone in the " $\mathrm{CaCO}_{3}-$ $\mathrm{CO}_{2}-\mathrm{H}_{2} \mathrm{O}$ ” system. AIChE Journal 50: 1908-1916.

Elless MP, Lee SY (1998) Uranium solubility of carbonate-rich Uranium-contaminated Soils. Water Air Soil Pollut. 107: 147-162.

Fanghänel Th., Neck V. (2002) Aquatic chemistry and solubility phenomena of actinide oxides/hydroxides. Pure Appl. Chem. 74: 1895-1907.

Felmy AR, Rai D, Hartley SA, LeGore VL (2002) Solubility and Leaching of Radionuclides in Site Decommissioning Management Plan (SDMP) Slags. Report NUREG/CR-6632. 60pp.

Froment P, Cara J, Ronneau C (2002) The solubilisation of Ru and U from condensation particles released $\mathrm{b}$ overheated nuclear fuel and maturated in air and in argon. Radiochim. Acta 90: 395-398.

Jerden Jr JL, Singha AK (2003) Phosphate based immobilization of uranium in an oxidizing bedrock aquifer. Appl Geochem 18: 823-843.

Junghans M, Helling C (1998) Historical Mining, uranium tailings and waste disposal at one site: Can it be managed? A hydrogeological analysis. In Tailings and Mine Waste '98, Balkema, Rotterdam, 117-126.

Kaplan DI, Serkiz SM (2001) Quantification of thorium and uranium sorption to contaminated sediments. J Radioanal Nucl Chem 248: 529-535.

Langmuir D (1997) Aqueous Environmental Geochemistry. Prentice Hall, 600 pp.

Lee J-U, Kim S-M, Kim K-W, Kim IS (2005) Microbial removal of uranium in uraniumbearing black shale. Chemosphere 59: 147-154.

Malmström ME, Destouni G, Banwart SA, Strömberg BHE (2000) Resolving the scaledependence of mineral weathering rates. Environ Sci Technol 34: 1375-1378.

Meinrath G, May P (2002) Thermodynamic prediction in the mine water environment. Mine Water Environ 21: 24-35.

Naftz D, Morrison SJ, Fuller CC, Davis JA (eds) (2002) Handbook of groundwater remediation using permeable reactive barriers-Applications to radionuclides, trace metals, and nutrients. Academic Press, San Diego, Calif., 539 pp.

Noubactep C (2003) Dissertation, TU Bergakademie Freiberg, Wiss. Mitt. Institut für Ge ologie der TU Bergakademie Freiberg, Band 21, 140 pp, ISSN1433-1284.

Noubactep C, Sonnefeld J, Sauter M (2005) Laboruntersuchungen zur Freisetzung von $U_{\text {nat }}$ aus einem Gestein unter oxischen Bedingungen. Grundwasser 10: 35-42.

Reeder RJ, Nugent M, Lamble G M, Tait CD, Morris DE (2000) Uranyl Incorporation into calcite and argonite. Environ Sci Technol 34: 638-644. 
435 Characterizing Uranium Solubilization Under Natural Near Oxic Conditions

Sherman LA, Barak P (2000) Solubility and Dissolution Kinetics of Dolomite in Ca-Mg$\mathrm{HCO}_{3} / \mathrm{CO}_{3}$ Solutions at $25^{\circ} \mathrm{C}$ and $0.1 \mathrm{MPa} \mathrm{CO}_{2}$. Soil Sci Soc Am J 64: 1959-1968.

Sun D-M, Wu Q-S (2004) Assembly synthesis of sheet-like calcite array and stable-vaterite by supported liquid membrane. Chin J Chem 22: 1067-1069.

Wilson M.J. (2004) Weathering of the primary rock-forming minerals: processes, products and rates. Clay Miner. 39: 233-266.

Xu T., Pruess K. (2000) in Proceedings World Geothermal Congress 2000 (Kyushu - Tohoku, Japan), 2983-2988. 